\title{
Government Regulation of Foreign Economic Activity in Russia: Legal and Economic Aspects
}

\author{
Z.K. Radzhabova ${ }^{1, *}$, O.R. Radzhabov², M.M. Osmanov,, T.G. Aygumov ${ }^{3}$, G.A. Emirova ${ }^{4}$ \\ and S.Z. Khidirova ${ }^{1}$
}

\begin{abstract}
${ }^{1}$ Department of ME and MB, Dagestan State University; ${ }^{2}$ Department Philosophy and History, FSBEI of HE "Dagestan State Agrarian University Named after M.M. Dzhanbulatova"; ${ }^{3}$ Cafe Computer Software and Automated Systems, FSBEI of HE "Dagestan State Technical University"; ${ }^{4}$ Cafe Law and Political Science, FSBEI of HE "Dagestan State Technical University", Russia
\end{abstract}

\begin{abstract}
The paper assesses the fact that in the current conditions of globalization, any national economy is becoming more open, and therefore the state should take into account in its trade and economic policy the consistent relationship between the processes occurring within the economy and in the sphere of foreign economic relations. The state also acts as the organizer of the system of servicing foreign economic relations and achieving internal economic equilibrium, and finances this activity from budgetary funds. This system is branched in its nature, covering such areas of activity as the provision of information and consulting services, and organization of advertising and exhibition work; it also helps to increase the efficiency of foreign economic activity, introducing new participants to it. The authors conclude that in order to maintain domestic economic balance, the state should strengthen its influence on imports in order to maintain domestic producers and without depriving them of competition from foreign goods at the same time.
\end{abstract}

Keywords: Economic sovereignty, Economic security, Coordination of interests, Foreign trade policy, Customs and tariff regulation.

\section{INTRODUCTION}

The role of government regulation of foreign economic activity lays in that the process of development of foreign economic relations, economic interests of various social groups and segments of the population clash to each other and the state inevitably becomes involved in this conflict of interests. In the context of globalization, the national economy is becoming more open; therefore, the state must take into account in its trade and economic policy the close interconnection between processes occurring within the economy and in the sphere of foreign economic relations (Caraka et al., 2021). Consequently, the state cannot achieve internal economic equilibrium without using foreign trade regulation. Caraka et al (2020) used location-based social vulnerability calculation involving the Information, Technology, and Communication, Food Access, Financial resource, household income, floods, earthquakes, COVID-19based on the National Socio-Economic Survey official reports. This problem has been and remains relevant now, since in the modern conditions of globalization, the problem of interaction between states is one of the most complex and interesting. To solve it, a deep study of the theory and history of the development of the government regulation system, the state of modern Russia and its relations with foreign countries is necessary. Foreign

*Address correspondence to this author at the Department of ME and MB, Dagestan State University, Russia; E-mail: r-zk@yandex.ru

E-ISSN: 1929-4409/21 economic activity is one of the spheres of economic activity of states, enterprises, and firms, which is closely related to foreign trade, export and import of goods, foreign loans and investments, and implementation of joint projects with other countries. Foreign economic activity should be understood as a combination of industrial, economic, organizational, economic and operational and commercial methods of implementing foreign economic relations, including trade, joint venture, the provision of various services, and other types of international cooperation. In turn, foreign economic relations are forms of economic, trade and other economic interstate relations, as well as some relations of a political, scientific and technical character at the interstate level in their totality and diversity.

\section{THE MAIN CONTRIBUTION OF GOVERNMENT REGULATION OF FOREIGN ECONOMIC ACTIVITY}

In accordance with the Federal Law of the Russian Federation dated December 8, 2003, No. 164-FZ "On the Basics of Government regulation of Foreign Trade Activity" (hereinafter - the Law), foreign trade activity should be understood as the activity on transactions in the field of foreign trade in goods, information, and intellectual property. Government regulation of foreign economic activity is a process consisting of the performance of certain functions by various authorities.

These include: creating the conditions for the effective integration of the Russian economy into the

(C) 2021 Lifescience Global 
global economy; protection of the economic sovereignty of the country; ensuring economic security of Russia; protection of interests of domestic entities of foreign economic activity in world markets; coordination of interests of various economic entities arising in the implementation of foreign economic activity; ensuring the balanced development of all types of foreign economic activity through the development and implementation of targeted comprehensive programs; improvement of the legal foundations of regulation, their harmonization and unification with generally accepted international norms and practice; provision of state budget revenues; scientific and informational and analytical support of foreign economic activity; creation of conditions for the provision by the foreign states and international organizations of advisory and technical assistance to the Russian Federation.

Article 4 of the Federal Law "On the Basics of Government regulation of Foreign Trade Activity" dated 08.12.2003 No. 164-FZ (hereinafter - the Law) establishes the principles of government regulation of foreign trade activity: the unity of foreign trade policy as an integral part of foreign policy; the unity of the government regulation system for foreign trade and control over its implementation; unity of export control policies; unity of the customs territory of the Russian Federation; equality of participants in foreign trade and the absence of their discrimination; state protection of the rights and legitimate interests of foreign trade participants; the exclusion of unjustified interference of the state and its bodies in foreign trade activities causing damage to their participants and the economy of the Russian Federation as a whole; priority of economic measures of government regulation of foreign trade activity (Gabrichidze 1995; Enggartyasti and Caraka, 2017).

State foreign trade policy is implemented through the application of economic and administrative methods of regulating foreign trade. Administrative measures can only be used if it is not possible to achieve the set goals with the help of economic measures. So, in accordance with Article 15 of the Law, quantitative restrictions on exports and imports, which are a kind of administrative restrictions on foreign trade, can be introduced only for exceptional purposes (to ensure national security of the Russian Federation, fulfillment of international obligations of the Russian Federation, etc.).

According to the legislation, the government regulation of foreign trade is carried out through both customs and tariff, and non-tariff regulations (http://www.cultline.ru/). The Law defines customs and tariff regulation as a method of government regulation of foreign trade in goods carried out by applying import and export customs duties. As for non-tariff regulation, it is carried out by introducing quantitative restrictions and other prohibitions, and economic restrictions. The mechanism of non-tariff regulation of foreign economic activity involves the use of economic methods (special and anti-dumping measures, and also currency regulation measures), and methods of administrative influence on participants in relations in the field of foreign economic activity (licensing, assignment of quotas, standardization) of a restrictive, prohibitive and permissive nature.

\section{METHODS}

We consider the instruments of tariff regulation of foreign economic activity. These include customs tariffs and customs duties. Customs tariff is a set of customs duty rates applicable to goods transported across the customs border of a country. The main objectives of the customs tariff of the Russian Federation (Ershov 2014): rationalization of the commodity structure of the import of goods into the Russian Federation; maintaining a rational ratio of export and import of goods, foreign exchange earnings and expenses on the territory of the Russian Federation; creating conditions for progressive changes in the structure of production and consumption of goods in the Russian Federation; protecting the Russian economy from the adverse effects of foreign competition; providing conditions for the effective integration of the Russian Federation into the global economy. The main functions of customs duties include protectionist, fiscal, and balancing.

The protectionist function is associated with an increase in the price of imported goods in the domestic market by levying a duty, which makes them less competitive, and accordingly protects national producers.

The fiscal function of the customs tariff ensures the receipt of funds from the collection of customs duties in the revenue part of the country's budget. Finally, the balancing function relates to exported goods and its purpose is to prevent unwanted export of goods, in particular, if their prices on the domestic market are lower than world prices.

In some cases, the customs tariff can be used to develop national exports by unilaterally setting low and, 
in some cases, zero rates for certain goods necessary for the manufacture of export products. Customs duty is a mandatory fee levied by the customs authorities when importing goods into the customs territory or exporting goods from this territory and it is an integral condition for such import and export.

Another group of methods for regulating foreign economic activity are non-tariff measures. There are a number of ways to classify non-tariff measures developed by the GATT / WTO, the UN Conference on Trade and Development, the International Monetary Fund, the World Bank, the International Bank for Reconstruction and Development, the International Chamber of Commerce, and several other reputable organizations (Ershov 2014; Kaban et al., 2019).

From the point of view of studying foreign experience in regulating foreign economic activity in modern conditions, all states without exception regulate their foreign economic policy through the customs tariff and through non-tariff restrictions. We show this with the example of individual countries.

\section{RESULTS}

In terms of the absolute volume of foreign trade, the United States is the largest trading power in the world. For example, in 2008, US exports totaled 1.29 trillion dollars, and in 2018 it was 2.23 trillion. \$ (Kislovsky 2017). Over the same period, Russian exports fell from \$ 471.8 billion in 2008 to $\$ 345.9$ billion in 2018 (Kozyrin 2017).

The primary means of regulating US imports are through customs duties on imports. The President of the country sets tariffs, provides preferences, and imposes an embargo on certain types of products.

In the United States, a customs tariff based on the Harmonized Tariff Schedule (HTS) of the naming and codification of goods developed with the participation of the Customs Cooperation Council is used. Tariff rates are presented in two columns, the first of which has two columns. The first column (the preferential tariff) contains duty rates applicable to goods imported from countries to which the United States applies preferential treatment. The second column (general rates) indicates the rates for goods in respect of which the most favored nation treatment applies.

An important role in customs regulation in the United States is played by the North American Free Trade Agreement (NAFTA) which entered into force on
January 1, 1994. It cancels customs duties on most goods imported into Canada, Mexico, and the United States for a transition period of no more than 15 years. For example, Canada and the United States have a free trade agreement that has abolished customs duties between the two countries.

A feature of the customs taxation of imported goods in the United States is its growth as the degree of processing of the goods and the size of capital and labor invested in its increase. Commodities, especially those that the United States cannot provide for itself from its own resources, are imported into the United States duty-free. The level of duties on semi-finished products, even when taxed at basic rates, is relatively low. The highest tariff rates apply to finished industrial products. The level of customs taxation of machinery and equipment, for example, at a preferential tariff is from 3 to $8 \%$, while at the main one it is $25-35 \%$ (Pecheritsa 2017). With the gradual decrease in US customs tariff rates, non-tariff barriers play an increasingly important role in the US market of goods supplied from foreign suppliers. The most common form of non-tariff restrictions on US imports is quantitative restrictions.

Some products are imported under quotas established by Congress through delegation of authority or by the federal government. These quotas specified in the Harmonized System are of two types: absolute and tariff. The absolute quota is the set amount of goods allowed for import. Such quotas limit the import of cheese, sugar, chocolate, condensed milk, some varieties of cotton, cotton yarn, peanuts, coffee, and certain types of rolled steel purchased by the United States. Tariff quotas allow the import of a product over a certain period with payment of duty at a reduced rate. Tariff quotas limit the import into the country of whole milk, fish, potatoes, and motorcycles of certain engine power.

Federal legislation provides for a large number of requirements regarding imported goods aimed at protecting the health and safety of people, and protecting animals or plants, works of art, as well as the correct application of tax legislation. In accordance with the 1979 Export Regulation Act, government export control is based on three criteria: US national security, national foreign policy considerations, and scarcity of goods on the domestic market. For reasons of national security, US exports of goods that can be used to strengthen the military capabilities of a potential adversary are controlled. To export these goods to all 
countries except Canada, an individual license is required in each case (http://www.ackpe.ru).

A number of restrictions may apply to the movement of goods and currency values between the United States and a certain number of countries and territories, up to the establishment of an embargo. For goods which price in the United States is lower than the price at which they are sold in the country of origin, anti-dumping duties may be set in order to protect American manufacturers. If they suspect that the price of imported goods is underestimated, an additional duty is imposed equal to the difference between the usual market price of the country of origin and the offer price in the US market. In the event that foreign goods imported into the United States are considered to be the subject of a subvention of a foreign state at the stage of production or export and this affects the sales of American manufacturers in the domestic market, a countervailing duty may be established. The various types of subventions that entail the use of countervailing duties include direct financial assistance, as well as tax exemptions, the provision of subventions for regional development, low-interest loans, and the promotion of modernization of production.

Great Britain. The government will give priority to the development of foreign trade and investment cooperation of the country with foreign countries. The basis of the UK customs legislation is the EU Customs Code of 1992 (EU Directive No. 913/92 dated October 12, 1992, establishing the Customs Code of the European Community). The Department of Business, Entrepreneurship and Regulatory Reform (DBERR) is empowered to formulate and implement foreign trade policies in the UK, including administrative and regulatory measures and rule-making functions aimed at supporting national producers and exporters. In the field of tariff regulation of imports, the basic document is the Integrated Tariff of the United Kingdom, which includes the Common Customs Tariff of the European Union, a system of statistical nomenclature, as well as a harmonized description and coding system for goods developed within the Customs Cooperation Council. In the United Kingdom, the product range, customs duty rates and procedures similar to those adopted in the EU Member States are applied. Goods from EU countries are imported duty-free; duties are applied when importing goods from outside the EU (http://www.ereport.ru).

Exports from the UK are carried out without restriction, with the exception of certain goods that are subject to the export control and licensing system. It should be noted that previously the main focus in the UK was made on issues of promoting the improvement of foreign economic activity in the country / regional context. Now the priority is given to the industry direction and then for each industry, its regional priorities are determined (the so-called "support of the British economy branches when entering the foreign market"). The Export Credit Guarantee Department (ECGD) is the organization that according to the government decision has the responsibility for providing guarantees in the field of foreign trade and investment. ECGD annually guarantees the export of UK companies and their investments in the amount of about 3.5 billion pounds sterling. The main part of its operations is to support the export of innovative goods (aircraft, other machinery and equipment) and services (the participation of British companies in international projects, primarily in the construction of large infrastructure facilities abroad, i.e. airports, power plants and hospitals, etc.).

Thus, the state encourages the export, first of all, of engineering and other products with a high level of added value.

\section{SOME FEATURES OF FOREIGN ECONOMIC ACTIVITY IN JAPAN}

We consider some features of foreign economic activity in Japan. The active participation of the state in the organization and implementation of foreign economic activity is a characteristic feature of Japan over the past four decades. The effectiveness of the Japanese foreign economic complex largely depends on the strength of its institutional foundations of foreign economic activity. In the system of government bodies in this area, administrative, coordination and advisory can be distinguished (http://www.customs.ru). Among the state administrative bodies, the Ministry of Foreign Trade and Industry holds a special place, which ensures the development of trade relations with foreign countries, solves foreign exchange issues related to foreign trade, promotes the production of export goods, sets quotas for the import of licensed goods, issues import permits, and determines the relevant trading rules.

Consistency and coherence in the implementation of trade and economic policy are largely ensured through close interagency coordination of government bodies. Interdepartmental coordination structures include the Trade Council, the Ministerial Conference 
on Economic Affairs, the Joint Headquarters of the Government and the ruling party for structural reforms. A feature of the Japanese system of government regulation concerning foreign economic activity is the availability of a large number (more than 200) of advisory bodies operating at various levels, up to the government and the prime minister.

The customs tariff is an important instrument for protecting national manufacturers, especially in the agricultural sector. The wider differentiation of customs tariff rates contributes to the solution of these problems. As an effective means of restricting imports, a system of strict technical and other special requirements regarding standards, certification, quality inspection, safety measures, etc. is widely used. A major role is played by economic levers of foreign economic activity regulation. An effective tool for lending to export-import operations and foreign investment of Japanese companies is Eximbank of Japan. The country has a system of tax incentives aimed at stimulating both export and import.

An important direction of state participation in foreign economic activity is the information support of commercial work, the collection and analysis of foreign commercial information. A special place in this series is occupied by the Japan External Trade Organization (JETRO) established in 1958. It is non-profit and is fully funded by the government. JETRO is engaged in the study of world commodity markets, the collection and analysis of marketing information, the organization of exhibitions of Japanese goods abroad and trade shows of other countries in Japan, and also advertising and publishing activity (Svinukhov and Scherbina 2018). The Japanese system of regulating foreign economic activity differs from its form of interaction between the state and business. It is based on the adoption by the private sector of the most important strategic directions of public policy, which is a kind of "state mentality" of this sector. This regulatory model using not only strictly administrative measures and methods, but also the "soft" forms that supplement them, can significantly increase the effectiveness of the public policy, organically combining it with the laws of the market.

\section{ACTIVITY IN CHINA}

State control of foreign trade in the People's Republic of China is carried out by the government and the Ministry of Foreign Trade. It manages sorting, import and export licensing, an inspection of foreign trade enterprises, control of the foreign exchange, restriction of export prices, protection of customs taxes, control and prohibition of smuggling. One of the main areas in the sphere of foreign trade regulation in the PRC after the country's accession to the WTO is the liberalization of the foreign trade regime. At the beginning of 2007, China had already fulfilled most of its duty reduction obligations.

In respect of goods which imports are limited in quantity, the state quotas system is in force in the PRC. Starting January 1, 2007, tariff quotas apply to seven types of agricultural products (wheat, corn, rice, sugar, wool, wool fibers, and cotton) and 3 types of chemical fertilizers. In order to promote exports, there are no export duties on the vast majority of goods. The practice of levying export duties is applied in China in relation to the export of certain goods which export is prohibited or restricted. In addition, the PRC has a procedure for returning VAT to exporters. The PRC export tariff contains 88 commodity items. Export duty rates are $20 \%-50 \%$ (http: / www. legalacts.ru; Feng 2016).

In accordance with applicable law, in China, a system of import and export licensing continues to be applied to a number of goods. Within the scope of their authority, licensing authorities issue licenses for the import and export of certain goods (http://www.ereport.ru). Joint orders of the Ministry of Commerce of the PRC and the Main Customs Administration of China annually approve the lists of goods which export and import is possible only upon receipt of an appropriate license. In China, the state permits the free import and export of goods and technologies, unless otherwise provided by laws or administrative regulations. Control over goods the export or import of which is limited is carried out in the form of issuing quotas, licenses and also through other methods. Control in the form of issuing licenses is also carried out in relation to technologies which export or import is limited. Export and import of goods and technologies that are subject to licensing are carried out according to the decisions of the State Council, through the issuance of permits by the department of the State Council that manages foreign trade, or by this department together with other relevant organizations within the State Council.

In recent years, China has reached a number of important bilateral and multilateral agreements. In particular, negotiations were held with a number of states on the recognition of the market status of the Chinese economy; currently, 2 states have officially 
recognized the market status of the Chinese economy. As part of the strategic objective of creating a free trade zone around China, practical work is also underway to implement agreements on the creation of a ChinaASEAN free trade zone, and also free trade zones with countries of the Southern African Development Community, countries of the Gulf Cooperation Council, New Zealand, Chile, Australia, and Pakistan. Practical work continued on the implementation of agreements at the bilateral level on the creation of free trade zones with Australia and New Zealand. In November 2005, the Free Trade Zone Agreement was signed between the PRC and the Republic of Chile. Back in mid-June 2003, China and Thailand signed an agreement on free trade in vegetables and fruits. On January 14, 2007 in Cebu (Philippines), China and ASEAN signed the Agreement on Trade in Services within the Free Trade Zone which served as a more solid basis for the timely completion of the construction of the China-ASEAN Free Trade Zone.

China is conducting a comprehensive reform of the legislative framework in the field of foreign trade to improve the welfare of the people of the country and the development of its state economy. Work is underway to expand the capabilities of Chinese national industries and various enterprises in the world market, as well as to protect their interests both in trade within the country and abroad.

In general, much attention is paid for the development of foreign trade activity and for its regulation by the state in Russia. Regulation of foreign economic activity has its own specificity in comparison with the regulation of other areas of the national economy. This specificity is due to the need for each state to reckon with international norms and principles of world trade.

Of particular importance for Russia and for the entire international system are relations with the United States of America, the People's Republic of China, India, as well as with the rapidly growing countries of the Asia-Pacific region, Latin America and Africa. And Russia is ready to take new steps to expand the scope and areas of interaction with these states, as well as strengthen cooperation in ensuring global and regional stability, increase mutual trade, investment, and develop people-to-people ties.

The process of Russia's entry into the constantly evolving world economy appears of particular relevance today while maintaining national security of the state and increasing the competitiveness of its products, both on the international and domestic markets. It is equally important to foresee how certain scenarios can affect Russia's place in the future multipolar world, striving to implement the most preferred option for the country.

\section{SUMMARY}

Thus, the development of foreign economic activity is facilitated by the world's largest system of state insurance of trade and investment. It includes general trade insurance, insurance of currency risks, export bills, export bonds, advance payments for imports, foreign investment, and loans to foreign enterprises.

The state also acts as the organizer of the system intended for servicing foreign economic relations and finances this activity from budgetary funds. This system is branched in nature, covering such areas of activity as the collection and analysis of marketing information, the provision of information and consulting services, the organization of advertising and exhibition work. It helps to increase the efficiency of foreign economic activity, introducing new participants to it.

\section{CONCLUSION}

In determining the role of the state in the regulation of imports, it should be borne in mind that imports, first of all, satisfy the demand of the population and in some sectors compensate for the shortage of domestic products. During the period of import liberalization, the domestic consumer market became almost monopolized by foreign manufacturers; the situation began to change only after a significant devaluation of the ruble, which reduced the competitiveness in Russia of foreign goods in price. In such a situation, it is necessary to strengthen the state influence on imports in order to support domestic manufacturers, at the same time, without depriving them of competition from foreign goods. With regard to improving the structure of imports, in our opinion, it is necessary to solve two strategic tasks for this: to reduce its consumer orientation (in this case, special attention should be paid to reducing or completely halting the procurement of products that do not contribute to the economic security of the country, including the food one); to reduce the import into the country of those goods that are advisable to produce domestically, and to satisfy the demand for them within the framework of import substitution. 
Scientific and technical products are one of the main foreign trade articles in any country, their size and structure reflects the economic development of the state. Next, it is necessary to increase the role of the state in the development and implementation of foreign economic relations, primarily the more efficient and effective use of tariff and non-tariff methods in their regulation. It is important to maintain a policy of increasing customs duties on unprocessed raw materials compared to processed products.

The development of bilateral and multilateral cooperation with the CIS member states is a priority area of the foreign economic policy of the Russian Federation. In the coming period, the priority areas for the development of interaction will be: improving the free trade regime in the CIS; the creation of elements of a single economic space: the movement of services, investments, and labor migration; interaction in the field of transport, including the formation of a network of international transport corridors; deepening cooperation in the field of energy in order to increase the reliability of energy supply and optimize the use of fuel and energy resources; the formation of interstate innovation space that promotes the effective use of scientific and technological developments and inventions, regardless of country of origin, based on national innovation systems; creation of effective mechanisms of payment and settlement relations.

\section{REFERENCES}

Caraka, R. E. (2020) 'Impact of COVID-19 large scale restriction on environment and economy in Indonesia', Global Journal of Environmental Science and Management, 6(Special Issue (Covid-19)), pp. 65-82.

Caraka, R. E. (2021) 'Cluster Around Latent Variable for Vulnerability Towards Natural Hazards, Non-Natural Hazards, Social Hazards in West Papua', IEEE Access. https://doi.org/10.1109/ACCESS.2020.3038883
Enggartyasti, A. and Caraka, R. E. (2017) 'A Preview of Total Quality Management (TQM) in Public Services', E-Jurnal Ekonomi dan Bisnis Universitas Udayana, 6(9). https://doi.org/10.24843/EEB.2017.v06.i09.p04

Ershov, A. D. 2014. "International Customs Relations." St. Petersburg, P. 45-47.

Federal Law dated 08.12.2003 N 164-FZ (revised on 07/13/2015) "On the Basics of Government regulation of Foreign Trade". Digital source - URL: Access mode: http: / www. legalacts.ru/doc/federalnyi-zakon-ot-08122003-n-164-fz-ob/

Feng, J. 2016. "Government regulation of foreign trade in China:" the thesis in support of the Candidate of Economic Sciences degree: 08.00.14.

Gabrichidze, B. N. 1995. "Customs law." - M. Publishing House "Beck", - P. 45

Guide for business: Great Britain is a trading partner of Russia [Digital source] URL: http://www.ackpe.ru/images/data/ gallery/0_9397_dlya_biznesa_2016__Velikobritaniya_19.06.doc

JETRO is the Japanese organization for the promotion of foreign trade. [Digital source] URL: http://www.cultline.ru/archiv/d/ 2953/

Kaban, P. A. (2019) 'Biclustering method to capture the spatial pattern and to identify the causes of social vulnerability in Indonesia: A new recommendation for disaster mitigation policy', Procedia Computer Science, 157, pp. 31-37. doi: 10.1016/j.procs.2019.08.138. https://doi.org/10.1016/i.procs.2019.08.138

Kislovsky, Yu. G. 2017. "History of customs and customs policy in Russia." - 3rd edition, supplemented. Under the general editorship of A. E. Zherikhov. - M: RUSINA-PRESS, P.156.

Kozyrin, A. G. 2017. "Features of non-tariff regulation of foreign economic activity in Japan." World Economy, 11, P.36.

Pecheritsa, V. F. 2017. "Customs and tariff regulation of foreign economic activity in the PRC in the context of globalization." Customs policy of Russia in the Far East 3(40): P.108

Svinukhov, V. G., and G. P. Scherbina. 2018. "Classification of nontariff regulation measures for the foreign trade in Russia." Law and Economics 8: - P. 18

Website of the Federal Customs Service of the Russian Federation URL: http://www.customs.ru

World Economy website [Digital source] URL: http://www.ereport.ru/ stat.php?count=usa\&razdel=country\&table=execia $\quad$ (access date: $04 / 15 / 2018$ ).

Received on 27-11-2020

Accepted on 31-12-2020

Published on 18-01-2021

DOI: https://doi.org/10.6000/1929-4409.2021.10.21

(c) 2021 Radzhabova et al.; Licensee Lifescience Global.

This is an open access article licensed under the terms of the Creative Commons Attribution Non-Commercial License (http://creativecommons.org/licenses/by-nc/3.0/) which permits unrestricted, non-commercial use, distribution and reproduction in any medium, provided the work is properly cited. 